\title{
Assessment of Compliance to Animal Source Foods Quality and Safety Standards in Uganda. A Case of Kampala and Mbarara Districts
}

Joseph M Kungu ( $\square$ joseph.kungu@mak.ac.ug )

Makerere University https://orcid.org/0000-0002-2225-463X

Francis Ejobi

Makerere University

Collins Atuheire

Makerere University

Sylivia Baluka

Makerere University

Dan Brian Kiganira

Makerere University

Edity Namyalo

Makerere University

Rehema Meeme

Uganda National Bureau of Standards

Bosco A Okuyo

Ministry of Agriculture Animal Industry and Fisheries

\section{Short Report}

Keywords: Animal source foods, food safety control, standards, stakeholders, market access, Uganda

Posted Date: December 2nd, 2021

DOI: https://doi.org/10.21203/rs.3.rs-1127861/v1

License: (9) (i) This work is licensed under a Creative Commons Attribution 4.0 International License. Read Full License 


\section{Abstract}

Animal source foods (ASFs) can be sources of illness when poorly handled both at the farms and during processing. Efforts have been undertaken by government to promote good food standards, quality and safety but have not paid off due to limited holistic involvement of all ASFs value chain actors like the farmers, transporters, traders, and the consumers. An assessment was conducted in Kampala and Mbarara districts to determine the level of compliance to existing food control standards.

The findings are to help inform policies to adapt, promote and implement standards and quality of ASF products free or with minimal contamination, services to promote local industries and protect consumers as well as facilitate access to international markets. This assessment was carried out in Kampala and Mbarara district with major objective of mapping various institutions involved in designing and implementing food control standards with the core mandate lying with Uganda National Bureau of Standards and assessing of compliance to food control standards along the ASFs value chain.

The studies were conducted in Kampala, Uganda's capital and Mbarara, the second biggest city in the country. These districts constitute the major market hub of agricultural products due to their high consumer population. The ASFs value chain assessments were conducted through workshops using focus group discussions with stakeholders in the meat, milk, poultry and fish value chains.

A number of organisations along the food chain were involved in designing and implementing of food safety standards and regulations, as well as regulatory norms for setting and controlling of quality standards for animal source foods in Uganda. These included; farmers, transporters, processors, academia, researchers, trade organisations, government institutions, private organisations, international bodies and consumers' organisations.

Majority of the outlet operators had both operating certificates and health certificates, however the remaining proportion that was noncompliant is still significant considering that they still distribute ASFs products. The study also observed that most of the measures required to ensure safety of ASFs are not followed along the food chain such as; poor transportation of animals and their products and use of antibiotics in animal feeds. It was also observed that product quality and cost of the product greatly contribute to the consumers' demand and confidence for a particular animal source product.

\section{Introduction}

\subsection{Background}

Animal source foods (ASFs) can be sources of illness when poorly handled both at the farms and during processing. There has been a steady increase in the demand of animal source foods majorly due to increase in the population, improved technology and also change in life style over time. ASFs particularly 
meat of a wide variety, fish, fowl meat, milk, eggs, snails, worms and other small animals supply not only high-quality and readily digested protein and energy, but also readily absorbable and bioavailable micronutrients (Neumann, et al., 2014). Consumption of ASF have numerous nutritional benefits like energy, proteins and other essential micronutrients to all people regardless of their socio-economic status and therefore, the safety of these foods for human consumption is key.

Presence of contaminants in these foods renders them not safe for human consumption and also reduces the access to both regional and international market. Animal source food contaminants include; microorganisms (viruses, bacteria and protozoa) and chemicals like drug residues, preservatives and heavy metals like lead.

Recent studies in Uganda, have shown that roasted beef sold in Central Uganda has high levels of inorganic pollutants (Bamuwamye et al., 2015; Ogwok et al., 2014) and in beef and milk in south-western Uganda (Kasozi et al, 2018). Accumulation of these pollutants in the human body may lead to health complication like growth retardation in children and cancers in both children and adults. There have been cases of use of insect repellents on beef by the butcher men which posed health concerns to the public, Rwanda and Kenya also banned the milk exports because of adulteration and EU banned the fish exports because poor fishing techniques that is; use of poison (Keizire, 2004; Mufumba, 2018).

The agriculture sector remains key in economic development of Uganda, with products generating revenue at local, regional (neighbouring countries) and global markets (especially European Union). To maintain market access and competitiveness at the regional and global levels, there is a high demand for consumer protection and compliance to both local and international guidelines, standards and regulations. The mandate to regulate the quality of animal source foods (ASFs) for consumption mainly lies with the government agencies at central and hardly at local levels.

In Uganda, regulation, certification, inspection and enforcement are undertaken by Ministry of Agriculture, Animal Industry and Fisheries in collaboration with other sectors like National Bureau of Standards (UNBS) and Ministry of trade. Considerable efforts have been undertaken to promote good food standards, quality and safety but have not been successful due to limited holistic involvement of other food value chain stakeholders like the farmers, transporters, traders, and consumers.

Since problems quantified are problems better managed, undertaking this project will help to map and characterize the food value chain actors as well as their respective obligations regarding developing and compliance to food safety standards. Sound scientific knowledge is expected to be generated to secure the provision of food products that are free from contamination or with a minimal risk of contamination. This will help in informing policies to adapt, promote and implement standards and quality of ASF products free or with minimal contamination and services to promote local industries and protect consumers as well as facilitate access to international markets.

\subsection{Livestock production in Uganda}


The livestock census done in 2018 in Uganda indicated that cattle were 14.6 million, goats were 16 million, sheep were 4.6 million, pig were 4.2 million and poultry were 48.9 million (UBOS 2019). It was also noted that the livestock are predominantly indigenous breeds (13.6 million cattle, 15.5 million goats and $85 \%$ of poultry).

Cattle and poultry are the most important species with their production valued at USD 8.9 million and USD 0.9 million respectively. 0.4 million tonnes of all kind of meat are produced per year, 211000 tonnes of beef per year worth USD 0.5 billion, 65000 tonnes of chicken meat per year worth of USD 87.7 million. 0.9 billion pieces of eggs are produced per year which generate USD 36 million, and 1.7 billion litres of milk are produced per year generating USD 0.5 billion.

In Uganda, milk is highly consumed as compared to other ASFs products with 36 litres, $14 \mathrm{~kg}$ of meat of all kind are consumed by every person, $6 \mathrm{~kg}$ of it is beef, 22 eggs and $0.8 \mathrm{~kg}$ chicken meat (FAO, 2019).

Uganda exports mainly meat, meat products, and dairy products and eggs which generate USD 6.2 million and USD 80 million respectively every year (FAO, 2019).

\subsection{The problem}

Raw and ready to eat animal source foods are potential vehicles for transmitting food-borne diseases, nutritional illness and enhance resistance to selected pathogens. Studies indicate that up to $14 \%$ of commonly reported conditions in developing countries are foodborne.

In Uganda, sale and consumption of ASFs is mostly through open permanent and temporary market outlets where inspection of food and food premises is hardly done, hence their safety not guaranteed. Modern outlets such as supermarkets and convenience stores selling branded ASFs in major towns like Arua, Gulu, Kampala, Jinja, Mbarara and Mbale are available but are avoided by most consumers due to higher prices and lack of confidence.

Considerable efforts have been undertaken to promote good food standards, quality and safety but have not been successful due to limited holistic involvement of other food value chain stakeholders like the farmers, transporters, traders, and the consumers. This has created gaps such as limited awareness about the regulations, non-compliance by stakeholders to existing food safety standards, hence the study.

\subsection{General objectives}

The general objective was to map the actors that are involved in designing and implementing ASFs safety standards as well assess their compliance to the existing standards in Uganda.

\section{Specific objectives}

1. Map the institutional stakeholders in charge of designing and implementing food safety standards in Uganda. 
2. Assess the stakeholder's compliance to standards and regulation in the animal source foods value chain.

3. Assess the drivers of consumer demand and confidence in animal source foods quality and safety.

\section{Methodology}

\subsection{Study design}

A mixed-methods cross-sectional study was conducted from December, 2019 to March, 2020 to assess stakeholders compliance to ASFs standards in Uganda.

It involved focus group discussions with the key stakeholders in the food value chain, which represented categories such as; farmers, regulatory agencies, transporters, processors and consumer protection organization among others.

A field survey of ASFs sale outlets was also done to assess level of compliance to certification instruments using a structured questionnaire in Kobo-collect data collection software .

\subsection{Study sites}

The study was carried out in Kampala and Mbarara districts. The two districts were considered because they constitute the largest hubs for both formal and non-formal markets for ASFs in the country.

Kampala district is the capital city of Uganda. According to the Uganda Bureau of Statistics (2020) the population of people in Kampala was estimated to be 1,659,600 (Uganda National Bureau of Statistics (UBOS), 2019). The district is located in the central region of the country, making it a market hub for livestock and ASF products from the rural communities of the different parts of the country. The district is also involved in livestock farming in its peri-urban settings (estimates; poultry, cattle, sheep, goats, pigs). Kampala has five divisions: Kawempe, Rubaga, Makindye, Nakawa and Kampala central administrative division.

Mbarara is in the Western part of the country, within the cattle corridor, with a population of 472,625 people (112,772 households), $43.5 \%$ of these engaging in livestock farming (National Housing and Population census, 2014).

\subsection{Data collection and analysis}

ASFs value chain assessments were conducted by holding stakeholders' workshops through focus group discussions (FGDs) at College of Veterinary Medicine Animal Resources and Biosecurity (COVAB), Makerere University and Mbarara animal reference laboratory.

The stakeholders were divided into four groups to discuss aspects regarding different ASFs components ( poultry, milk, meat and fish) in line with the 3 specific objectives of the study. A total of 8 FGDs, consisting of 8-10 participants from various nodes of the ASFs value chain were conducted. 
A structured questionnaire was developed and used to collect data from key stakeholders that is milk and meat outlet attendants and consumers using the Kobo collect data collection tool.

\section{Data Analysis}

The recorded audio files of focus group discussions were translated into English and after transcribed into Ms word files by JMK, DK and EN. The transcribed data was then transferred to QDA Minor Lite (version1.4.1) for coding into themes based on the objectives of the study (Provalis Research, 2014).

Summarized narratives under each theme were also generated. Key illustrative quotations of the FGDs have also been reported under the themes. The themes included demographic and socioeconomic characteristics. Descriptive data analysis was done to determine the drivers of consumer confidence and instruments of certification.

\subsection{Ethical approval and consent to participate}

The study proposal was submitted for approval to the Research and Ethics Committee of the College of Veterinary Medicine, Animal Resources and Biosecurity of Makerere University (Reference Number:VAB/REC/20/03).

Prior to the study, written permission was obtained from Ministry of Health and Ministry of Agriculture Animal Industry and Fisheries of the government of the republic of Uganda.

\section{Findings}

\subsection{Stakeholder institutions in charge of designing and implementing ASF safety standards}

Although several government institutions were identified as key in designing and enforcing of ASF safety standards, the core mandate of food control lies with Uganda National Bureau of standards in the country (Table 1). The UNBS is expected to transparently ensure the safety and quality of food, and prevent fraudulent practices thereby enhancing consumer protection, promotion of food trade and industry locally and internationally. The UNBS, basing on the guiding principles of the Codex Alimentarius Commision operates at the interface of government ministries (MAAIF, MOH, Ministry of Trade and Industry) and all other food chain actors (consumers, transporters, producers, marketers). Although the UNBS is a considerably independent agency with most of stipulated structures in place, it is grappling with financial and staffing challenges that make it difficult to coordinate with other key stakeholder institutions in implementing of food control activities. The participants observed that the ASFs consuming public was not being provided with facts that should enable them to make informed choices on the appropriate food products. It was also observed that there was a need for UNBS to initiate and promote a platform for involvement of all ASFs value chain actors in formulation and enforcement of food control policies. 'Open and transparent decision-making processes need to be encouraged to 
enhance the vigilance of the public to willingly comply to food control standards and promote ASF safety', said a participant.

Since the UNBS has the statutory authority to oversee formulation and review of standards, responsibilities include the identification of legislative needs; monitoring the efficiency and effectiveness of law enforcement and food surveillance activities; commissioning research; etc;

In order for UNBS to successfully undertake its statutory roles (coordination, monitoring and auditing), it should closely work with the associated government ministries and all the ASFs actor institutions in implementing food control activities (food analysis, inspection, enforcement, and sensitization). 
Table 1

Institutions involved in designing and implementation of ASF safety standards

$\begin{array}{lll}\text { Institution } & \text { Role } & \text { ASF } \\ & & \text { Component }\end{array}$

Uganda Formulation and enforcement of standards at abattoirs and meat

National

Bureau of

factories and supermarkets.

Standards Certification of packaged ASFs.

Meat, milk, poultry and fish

(UNBS)

Ministry of Formulation, review and enforcement of ASF standards.

Meat, milk,

Agriculture,

Animal

Industry and

Fisheries

(MAAIF)

It regulates use of veterinary drugs, feeds and other livestock farm poultry and fish inputs, provides extension services such as training of farmers and capacity building of extension staff as well as guiding standards development processes.

It controls and manages epidemics and disasters, and support the control of sporadic and endemic diseases, pests and vectors.

It is also responsible for inspection and certification of livestock and its products for the local market and export.

Ministry of Involved in formulation of policies and regulations

Trade

Meat, milk, poultry and fish

Ministry of

Involved in enforcement of standards through its public health arm of

Health

$(\mathrm{MOH})$ inspection of premises of sale ASFs as well as the products themselves.

Meat, milk, poultry and fish

Ministry of water and

Through the National Environment authority enforces standards by environment providing clearance for establishment of facilities such as farms, abattoirs, food processing industries among others. This is done to ensure that establishment of these facilities does not compromise the ecosystem.

Academic Training institutions such as Makerere University conduct research on institutions feeds, animal diseases, animal breeds, which helps inform the standard formulating processes. These institutions provide relevant training to students (e.g., veterinary doctors, food safety specialists) and also offer trainings and consultancy services to livestock farmers and business entrepreneurs.

Research institutions
The examples include: Uganda Industrial Research Institute (UIRI), National Agricultural Research Organization (NARO) and International Livestock Research Institute (ILRI), National genetic resources and data bank (NAGRICDB). These carry out research and innovations that provide evidence to support formulation of standards.
Meat, milk, poultry and fish

Meat, milk, poultry and fish

Meat, milk, poultry and fish 


\begin{tabular}{|lll|}
\hline Institution & Role & $\begin{array}{c}\text { ASF } \\
\text { Component }\end{array}$ \\
\hline $\begin{array}{l}\text { ASF actor } \\
\text { groups }\end{array}$ & $\begin{array}{l}\text { These ASFs value chain actors are the main end users of the } \\
\text { standards, although they are not well organized. They are expected to } \\
\text { provide awarens, play mobilisation roles about the quality } \\
\text { requirement of the animal source foods. These associations include } \\
\text { farmers' associations (dairy farmers network), traders' associations, } \\
\text { transporters' associations (Dairy transporters association). Uganda }\end{array}$ & $\begin{array}{l}\text { Meat, milk, } \\
\text { poultry and } \\
\text { fish }\end{array}$ \\
& $\begin{array}{l}\text { Fish Processors and Exporters Association(UFPEA), Walimi Fish } \\
\text { Farmers Cooperative Society (WAFICOS), L. Victoria Fishers } \\
\text { association }\end{array}$ & \\
$\begin{array}{l}\text { Dairy } \\
\text { development } \\
\text { authority } \\
\text { (DDA) }\end{array}$ & $\begin{array}{l}\text { The agency regulates quality and transportation of milk, certification } \\
\text { of transport and quality, quality monitoring, and capacity building. }\end{array}$ & $\begin{array}{l}\text { Milk } \\
\text { products }\end{array}$ \\
\hline $\begin{array}{l}\text { Security } \\
\text { agencies }\end{array}$ & $\begin{array}{l}\text { Uganda Peoples Defense Force (UPDF) and Uganda Police (UP) have } \\
\text { units that work with MAAIF to enforce adherence to the standards. }\end{array}$ & $\begin{array}{l}\text { Meat, milk, } \\
\text { poultry and } \\
\text { fish }\end{array}$ \\
\hline & $\begin{array}{l}\text { Examples are the animal quarantine enforcement and fisheries } \\
\text { protective unit which enforces good fishing practices. }\end{array}$ & \\
\hline
\end{tabular}

\subsection{Stakeholders' compliance to standards in the animal source foods value chain}

Safe food is generally defined as food free of hazards to human health. Safety can be seen as an aspect of food quality, which encompasses all attributes of food (such as freshness, nutritive value, taste, origin) that influence its value to consumers.

Unsafe food containing harmful bacteria, viruses, parasites or chemical substances, causes more than 200 diseases for example typhoid, Bovine tuberculosis, brucellosis, among others. Diarrhoeal diseases are the most common illnesses resulting from the consumption of contaminated food, causing $\mathbf{5 5 0}$ million people to fall ill and 230000 deaths every year (World Health Organization, 2020).

The Codex Alimentarius international food standards, guidelines and codes of practice contribute to the safety, quality and fairness of international food trade. This also ensures the protection of the consumers health. Veterinary drugs, pesticides, food additives and other contaminants are some of the issues discussed in Codex meetings. Once the Codex standards are fulfilled, it removes the barriers to trade by resolving trade disputes through World Trade Organization.

In Uganda national bureau standards has documented standards for different animal products (UNBS), for example;

US codex stan 89-1981 (revised in 2015). This applies to products designated as "luncheon meat" which have been packed in any suitable packaging material.

US 737:2007. This standard specifies requirements for the production of packaged meat products (processed or manufactured) processed in an established meat processing factory. 
US CAC/RCP 15:1976. This Code of Hygienic Practice for eggs and egg products is intended to provide guidance for the safe production of eggs and egg products

US 806:2009. This standard prescribes specifications for the following poultry feeds: broiler starter feed, broilers finishing feed, chick and duck feed, poultry grower feed, turkey starter feed, layer feed and breeders feed.

\subsubsection{At the farm.}

In order to ensure that ASFs produced for human consumption is safe from hazards, farmers are expected to play a crucial role of preventing livestock and its products from getting contaminated with biological (bacteria, viruses and fungi), chemical (antibiotics, inorganic compounds) and physical (adulterations) agents at production level. It was observed in this study that previously, there have been no deliberate efforts envisaged to support farmers to implement safe food production. This is however expected to change with the government's current move of promoting commercialized production through modernization of agriculture programs to improve livelihoods and boost economy.

'Most of the farmers have been keeping livestock on subsistence basis, producing mainly for consumption at home and within the local community setting. Due to the increasing demand for ASFs, livestock farming is becoming highly commercialized, with farmers aiming to produce on large scale to address the demand locally and internationally.'

Increasing investment in livestock sector to boost the economic returns is expected to act as an incentive that will compel the farmers and the government to ensure compliance to food control practices so as to maximize profits locally and from exports.

During the discussions, case scenarios of noncompliance to food control practices were noted and solutions proposed as summarised below:

Sale of poor quality livestock; Farmers tend to sell off livestock that are unthrifty, have failed to recover following treatment and are no longer productive to avoid making losses. This poses public health risks due to zoonoses. Whenever I go to my village, I avoid buying cattle meat because they will only slaughter those that are sick. It is safer to buy goat or sheep meat instead because they are usually slaughtered when healthy due to their body sizes.'Explained a participant.

Sale of adulterated livestock products; Farmers harvest ASFs (milk, eggs, fish and meat) without strictly following drug withdrawal periods after treating their animals, exposing consumers to antimicrobial resistance. Poultry farmers deliberately add antibiotics to feeds and water as growth promoters without considering the health implications to consumers. There is no way a farmer can raise exotic chicken without routinely administering to them drugs to boost their immunity. It is even worse with broilers' Kampala FGD participant. 
Some farmers who sell milk add water to increase quantity. 'Door to door milk suppliers have a habit of adding water to milk, especially during dry season when feeds are scarce to meet the demand of their clients.'said a Kampala FGD participant.

'Scenarios of milk adulteration are being curbed by testing of milk at bulking centres using lactometers. Private companies that buy milk are so strict so that if the milk collected at the centres is tested and detected to have water, it will be rejected and becomes a loss to all farmers who would have bulked their milk at that centre. 'Mbarara FGD participant.

Use of poor quality feeds and water, Animals are given inadequate feeds and water that are of poor quality, thereby affecting their health and the quality of their products. 'Feeds should meet the nutritional needs of animals, quality water supplies should be provided, regularly checked and maintained. Control of storage conditions of feed and traceability of feedstuffs brought to the farm should be emphasized to prevent the risk of aflatoxicosis. 'Declared participant in Mbarara.

Unhygienic farm environment; This leads to contamination of feeds and water, making livestock sick. Products such as milk and eggs also directly get contaminated during the process of harvest and storage.

So as to produce ASFs fit for human consumption, farmers need to be advised on appropriate farm biosecurity measures aimed at preventing disease occurrence hence raising healthy livestock that meet requirements for both local and international market.

\subsubsection{Transportation of animals and animal products.}

During transportation, there are recommended conditions required for transportation of live animals and their products like milk, carcases and eggs. These conditions include but not limited to temperatures and animal welfare to ensure safety and adequate nutrition content of the products.

'All animals destined for slaughter should be clean, healthy and fit to travel and have not had recent contact with diseased stock or infectious material and the records of animals and animal products leaving the farm as well as their destination and date of dispatch should be kept. In addition, treatment withdrawal periods should be observed before animals are slaughtered.

Recommended storage conditions should be observed to maintain the quality of the products especially for milk and eggs.' Kampala FGD participant.

Transportation should be done well to avoid soiling and cross-contamination with faecal material, ensure that no new hazards are introduced during transport, and records to enable animal identification should be kept as well. Restraint and handling of animals prior to loading is expected to be done in a safe and humane manner. Although there are standards that ought to guide handling and transportation of livestock and livestock products (US733), these are ignored. It was reported by participants that live animals were often packed and poorly transported in unspecialized means that included trucks, pickups, 
taxis, bicycles and motorcycles (bodaboda). 'It is such a terrible scene at the livestock markets if you are to witness how the transporters beat up and overload animals in trucks. These people are so cruel to these animals, probably knowing that they are headed for slaughter anyway.'Kampala FGD participant.

'Quite often, taxis from Eastern routes come to Kampala loaded with poultry on their racks. Sometimes these birds die in transit and are likely to be roasted chicken pieces sold cheaply on the streets.'Kampala participant.

The transportation of milk, eggs and fish products for longer distances is done more carefully to avoid spoilage before reaching market destination. This is usually done using refrigerated vehicles (milk and fish) and crates/ boxes (eggs). The only challenge in this case is maintaining cleanness of these vehicles, containers and boxes.

There is also the challenge of using inappropriate containers (polythene bags, jerrycans) instead of using milk cans when transporting milk from the farms to collection centres or nearby sale outlets.

Transport vehicles for live animals and ASF products, containers and boxes should be designed for specific animal species while ensuring adequate spacing, ventilation and cleanness maintenance.

\subsubsection{Processing of ASFs.}

During processing, good hygiene practices are paramount in both slaughter houses and factories to prevent contamination of the products. In addition, products are supposed to be packaged in food grade materials and the handlers are supposed to undergo health assessment and issued with certificates to handle animal products. Products should be well packaged and labelled with required information like nutrition content, storage and preparation conditions, manufacture and expiry date among others. The following are the key quotes of participants regarding the status of ASFs processing;

"Most of the abattoirs are privately owned, so they should be able to improve the standards of the abattoirs. However, constructing and renovating an abattoir to a recommended standard is quite expensive which the private owners are definitely not able raise. Could it be that the meat inspectors don't do their work? It's urged that it's the responsibility of the owners to seek help of the technical people. The government has tried to renovate its abattoirs for example the Uganda meat industry has been closed since last year to enable renovations, this however may not be replicated in the privately owned settings. " said a participant in Mbarara.

'Bombo meat abattoir is the only one certified by ISO in Uganda but most businessmen/farmers prefer other slaughter houses since Bombo charges (approximately 100,000/= per cow slaughtered) are higher than the uncertified abattoirs. Kampala participant.

\subsubsection{Distribution, retail and home preparation.}

This should be done under proper conditions considering temperature, moisture, hygiene and also proper handling during loading and offloading of the products. At retail shops and home, proper handling and 
storage conditions need to be considered to prevent contamination of the products.

The participants agreed that regulations and laws should be put in place to implicate milk sellers including small outlets and door to door vendors who use plastic containers or jerrycans to sell milk.

"Public sensitization targeting both vendors and consumers of unpackaged milk about qualities of safe and good milk should be done. They can also be advised to shun away from buying milk carried in plastic containers", noted a participant in Mbarara.

\subsubsection{Fish sector specific food control challenges.}

Standards for food control in the fish sector exist and they include; Fish net standards for different fish sizes, Code of practice for fish and fish products (codex), Code of Practice for fish handling and processing fresh fish, boat registration and tracking policy. The key quotes on status of fishing in Uganda are summarised below;

- In the 1990's fishing was done using chemicals and this led to fish ban on the international market and also compromised the safety of the public, Landing sites never had cooling facilities, toilets and other sanitary facilities, Fish net sizes were not regulated resulting in low fish stock in the water bodies especially L. Victoria.

- Now, there is regulation such as registration of boat owners, breeding grounds are protected, army on lakes and landing sites enforcing regulations in place, banning fish nets of wrong sizes. There is an increase in demand for fish, most especially fish maw (swim bladder) due to its high demand for medicinal purposes for example manufacturing of sutures.

- Fish farming has been introduced and is being popularized to meet the increase in demand hence relieving the over-fishing pressure on the natural water sources.

Case scenarios of poor food safety control identified included;

- Use of chemicals to trap fish

- Poor sanitation at landing site; no or inadequate toilets, bad fishing techniques like typhooning and use of microfilament nets.

- Poor handling practices for example smoking of fish was never done using the recommended wood (hard wood), drying mukene was done on the ground or it would be mixed with sand to increase weight, cold storage facilities were lacking at the landing sites.

- Fish are sometimes captured, their swim bladder removed and the fish are then dumped back into the lake, depleting the stock.

- High-handedness of security personnel (UPDF marines) during enforcement of fishing guidelines on natural water bodies. Some stakeholders emphasized that "UPDF is on the lake for selfish reasons that is trade of the expensive and highly demanded swim bladder. 'UPDF has supported the regulations to implement rules however, stakeholders believe that there is need to strengthen and empower the agriculture police to replace UPDF on L. Victoria.' 


\subsection{Drivers of consumer confidence in animal source foods.}

Product quality was reported to be the leading factor that builds consumer confidence in a particular product, followed by cost of a product, as well as how a product is packaged and handled. Despite its importance in food control, certification of products scored the least as according to the survey responses as shown in figure 1.

\subsection{Certification and inspection}

Assessment of instruments of certification of quality of ASFs such as possession a valid public health certificate, meat inspection seal and a valid operating license was conducted using a structured questionnaire in selected meat sale outlets in Kampala and Mbarara districts.

It was generally observed that more than $55 \%$ of the meat sale outlets surveyed had in place the instruments of certification and inspection. Most of the outlets sold meat that had a stamp (80.0\%Kampala, $68 \% \mathrm{Mbarara}$ ) which indicates that it was inspected by both public health and veterinary officials and was safe for consumption. Majority of the ASF handlers had public health certificates $(67 \%$ Kampala, $60 \%$ Mbarara). Up to $60 \%$ (Kampala) and 58\% (Mbarara) of the meat outlets had valid operating licences from the appropriate authorities. This implies that the other outlets $40 \%$ (Kampala) and $42 \%$ (Mbarara) were illegally operating without the required licences. Frequency of use of instruments of certification and inspection was higher in Kampala compared to Mbarara district as shown in figure 2.

Certification is a process of making an official statement confirming the truth of inspection has been carried out accurately, satisfactorily, considering evidence of compliance to required food control standards.

In Uganda, inspection \& certification is carried out by the division of Veterinary Regulation \& Enforcement in the department of animal health in the Directorate of Animal Resources. The department works together with the Division of Veterinary Public Health in department of Animal Production. These departments carryout inspection \& certification of all exports of animals, animal products, by-products and inputs, approves establishments for production and slaughter \& processing of animals \& products, undertakes import risk analysis for importation of animals, animal products and inputs, disease surveillance among others.

Inspection is carried out on; live domestic animals, animal products (meat, milk, eggs, chicken, hides \& skins), feeds \& feed additives, semen, ova, embryos, wild animals, wild animal products (skins, skull, teeth), equipment and devices, vessels for carrying animals, premises (production \& processing) among others. These departments work jointly with other stakeholders for example; $\mathrm{MOH}$ (Public health), UWA (wild animals/products), UNBS (foods), NAGRC \& DB (semen, ova), DDA (milk) among others. 


\section{Conclusion And Recommendations}

\subsection{Conclusion}

A number of organisations at all levels of the food chain are supposed to be involved in designing and implementing of food safety standards and regulation, and develop and implementing of regulatory norms for setting and controlling of quality standards for animal source foods in Uganda. These include; farmers, transporters, processors, academia, researchers, trade organisations, government institutions, private organisations, international bodies and consumers' organisations.

Majority of the outlet operators had both operating certificates and health certificates, however the remaining proportion that was noncompliant is still significant considering that they still distribute ASFs products. The study also observed that most of the measures required to ensure safe ASFs are not followed along the food chain for example; poor transportation of animals and their products, and use of antibiotics in animal feeds.

A survey showed that product quality and cost of the product greatly contribute to the consumers' demand and confidence for a particular animal source product. There is also knowledge gap among the consumers regarding key factors that should be considered before buying ASF products from the outlets since possession of health certificate and operating licence scored lowest in the survey.

\subsection{Recommendations}

The government should revise the budget allocated to UNBS to ensure availability of resources (funds and human labour), in order to facilitate adequate coordination and implementation of food control activities.

Concerned institutions like KCCA and DDA should intensify spot on field inspections to ensure compliance of all the operating ASFs outlets with trading, sanitary and health standards required. The non-compliant outlets should be closed and those responsible severely penalised.

There is still need for extensive sensitization and training of the general public and other stakeholders especially farmers, transporters and distributers about major factors that affect food safety of ASFs and the economic and health benefits of production of safe ASFs.

Government should develop and implement a policy on antibiotic use especially in the agriculture sector as cited in the stakeholders' meeting. The policy should clearly state the different roles for various key players in ensuring that no drug residues are retained in ASFs products hence slowing AMR and increasing international market accessibility.

More abattoirs should be certified by ISO and the price charged for animal slaughter can be revised to ensure affordability. 
There is need to review the existing ASFs control standards to ensure they meet the changing requirements for market access locally and internationally.

\section{Declarations}

\section{ACKNOWLEDGEMENT}

We would like to express our sincere gratitude to Makerere University Research and Innovation Grant and the Government of the Republic of Uganda for the golden opportunity given to us to carry out this very important project.

Special thanks go to Makerere University, College of Veterinary Medicine Animal Resources and Biosecurity, all stakeholders who participated in focused group discussions, and research assistants involved in data collection.

Competing interests: The authors declare no competing interests.

\section{Abbreviations}

ASF

AMR

DDA

EU

FAO

ISO

KCCA

MAAIF

$\mathrm{MOH}$

NAGRIC/DB

UBOS

UNBS

USD

UWA
- Animal Source foods

- Antimicrobial Resistance

- Diary Development Authority

- European Union

- Food and Agriculture Organization

- International Organization for Standardization

- Kampala Capital City Authority

- Ministry of Agriculture Animal Industry and Fisheries

- Ministry of Health

- National Animal Genetic Resource centre and Data Bank

- Uganda Bureau of Statistics

- Uganda National Bureau of Standards

- United States Dollar

- Uganda Wildlife Authority 


$\begin{array}{ll}\text { Et al } & \text { - Et alia (others) } \\ \text { e.g } & \text { - For example } \\ \text { etc. } & \text { - et cetera (And so forth) } \\ \% & \text { - Percentage } \\ \mathrm{Kg} & \text { - kilogram }\end{array}$

\section{References}

Bamuwamye, M., Ogwok, P., \& Tumuhairwe, V. (2015). Cancer and Non-cancer Risks Associated With Heavy Metal Exposures from Street Foods: Evaluation of Roasted Meats in an Urban Setting. Journal of Environment Pollution and Human Health, 3(2), 24-30. https://doi.org/10.12691/jephh-3-2-1

Food and Agriculture Organization of the United Nations (FAO), \& Development, I. (2019). Africa Sustainable Livestock 2050: The future livestock in Uganda opportunities and challenges in the face of uncertainty.

Keizire, B. B. (2004). Policy Research - Implications of Liberalisation of Fish Trade for Developing Countries; A Case Study for Uganda.

Mufumba. (2018, January 13). How safe is food on the market? Dily Monitor News Paper, Uganda. Retrieved from https://www.monitor.co.ug/uganda/magazines/people-power/how-safe-is-food-on-themarket-1735366\%0AUganda

Neumann, C. G., Bwibo, N. O., Gewa, C. A., \& Drorbaugh, N. (2014). Animal source foods as a food-based approach to improve diet and nutrition outcomes . In L. Thompson, B., Amoroso (Ed.), Improving diets and nutrition: food-based approaches (p. 157). https://doi.org/10.1079/9781780642994.Chapter

Ogwok, P., Bamuwamye, M., Apili, G., \& Musalima, J. H. (2014). Health Risk Posed by Lead, Copper and Iron via Consumption of Organ Meats in Kampala City (Uganda ). 2(3), 69-73. https://doi.org/10.12691/jephh-2-3-3

Provalis Research. (2014). QDA Minor Lite. Free Qualitative Data Analysis Software. https://doi.org/v1.4.1

Uganda National Bureau of Statistics (UBOS). (2019). Uganda bureau of statistics 2019 statistical abstract.

World Health Organization. (2020). Food safety Chemicals: Retrieved from https://www.who.int/newsroom/fact-sheets/detail/food-safety

\section{Appendices}


LIST OF PARTICIPANTS INVOLVED IN FOCUSED GROUP DISCUSIONS

Meat sector (Beef, pork and mutton)

\begin{tabular}{|c|c|c|}
\hline No. & Name & Institution \\
\hline 1 & Mr. Peter Kisambira/ & UNFFE \\
\hline 2 & Prof. Charles Muyanja & $\begin{array}{l}\text { School of Food Technology, Nutrition and Bioengineering, Makerere } \\
\text { University }\end{array}$ \\
\hline 3 & Dr. Francis Jumba & UMPC \\
\hline 4 & $\begin{array}{l}\text { Dr. Emilian } \\
\text { Ahimbisibwe }\end{array}$ & KCCA \\
\hline 5 & Mr. John Semolya & Casseroles Enterprises \\
\hline 6 & Mr. Mahmod Mbaziira & UNBS - Certification \\
\hline 7 & Hajji Ediris Sekitoleko & KABUTA \\
\hline 8 & Mr. George Gafabusa & Choice cuts Ltd \\
\hline 9 & Mr. David Mutei & Uganda Cattle traders Association \\
\hline 10 & Mr. Ahmed Mpungu & Uganda Farmers Meat Company \\
\hline 11 & $\begin{array}{l}\text { Mr. Christopher } \\
\text { Mulindwa }\end{array}$ & Farmer - pigs \\
\hline 12 & Musisi John & KCCA Abattoir \\
\hline 13 & Nakedde David & KCCA Abattoir \\
\hline \multirow[t]{4}{*}{14} & Omagor Samuel & UMI abattoir \\
\hline & Facilitators & \\
\hline & Dr. Joseph Kungu & COVAB \\
\hline & Prof. Francis Ejobi & COVAB \\
\hline
\end{tabular}

Poultry sector 


\begin{tabular}{|lll|}
\hline No. & Name & Institution \\
\hline $\mathbf{1}$ & Mr. Usaama Bulimbo & Luuka plastics Ltd \\
\hline $\mathbf{2}$ & Ms. Dorah Nanyondwa & YASH Itd \\
\hline $\mathbf{3}$ & Ms. Susan Nyakato & Ugachick \\
\hline $\mathbf{4}$ & Ssentongo Remmy & Biyinzika \\
\hline $\mathbf{6}$ & Akankwasa Alfred & \\
\hline $\mathbf{7}$ & Mr. Francis Mukalazi & MTIC \\
\hline $\mathbf{8}$ & Ms. Mary Seviin & Fresh cuts Ltd \\
\hline $\mathbf{9}$ & Kairu Kirizostom & Biyinzika \\
\hline & Facilitators & \\
\hline & DanBrian Kiganira & \\
\hline & Ms. Rehema Meeme & UNBS- Standards Department \\
\hline
\end{tabular}

Fish sector

\begin{tabular}{|lll|}
\hline No. & Name & Institution \\
\hline 1 & Mr. James Wire & Realm Foods Ltd \\
\hline 2 & Mr. Allen Kusasira & SON Fish Farm Ltd \\
\hline 3 & Ms. Elizabeth Nyakaisiki & UNBS- Microbiology Lab \\
\hline 4 & Mr. Mark Matisko & UIRI \\
\hline 5 & Ms. Joan Kyokutamba & UCPA \\
\hline 6 & Mr. Moses Byentaro & Mukwano group of companies \\
\hline 7 & Dr. Jacob Mukose & MAAIF - SVO - Marketing \\
\hline 8 & Mr. Matovu Moses & \\
\hline & Facilitator & \\
\hline & Ms. Edith Namyalo & COVAB \\
\hline
\end{tabular}


Milk Sector

\begin{tabular}{|lll|}
\hline No. & Name & Institution \\
\hline $\mathbf{1}$ & Dr. Allan Asiimwe & MAAIF \\
\hline $\mathbf{2}$ & Mr. Wilber Waibale & UIRI \\
\hline 3 & Mr. Mukasa Vianney & Fido dido Industries Ltd \\
\hline 4 & Mr. Godffrey Byaruhanga & NARO- NAFIRRI \\
\hline 5 & Dr. Reuben & DDA- inspection \\
& Kawagga & \\
\hline 6 & Dr. Jolly Kabirizi & Farmer -Beef \\
\hline 7 & Ms. Mary Nakibuuka & UNBS- testing \\
\hline 8 & Dr. Bagumire Ananius & Food safety Associates \\
& Facilitator & \\
& Ms. Yvette ssebunya & COVAB \\
\hline
\end{tabular}

\section{Figures}

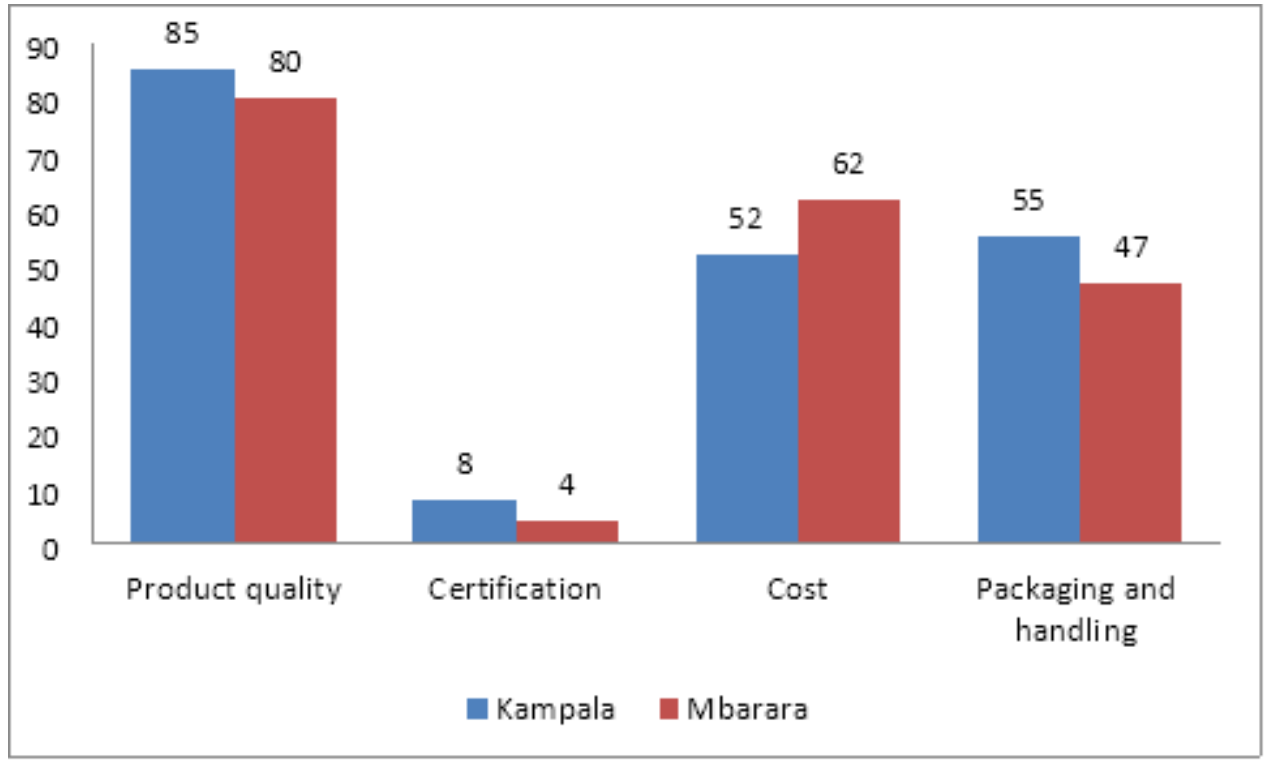

Figure 1

Factors influencing consumer confidence in Kampala and Mbarara districts 


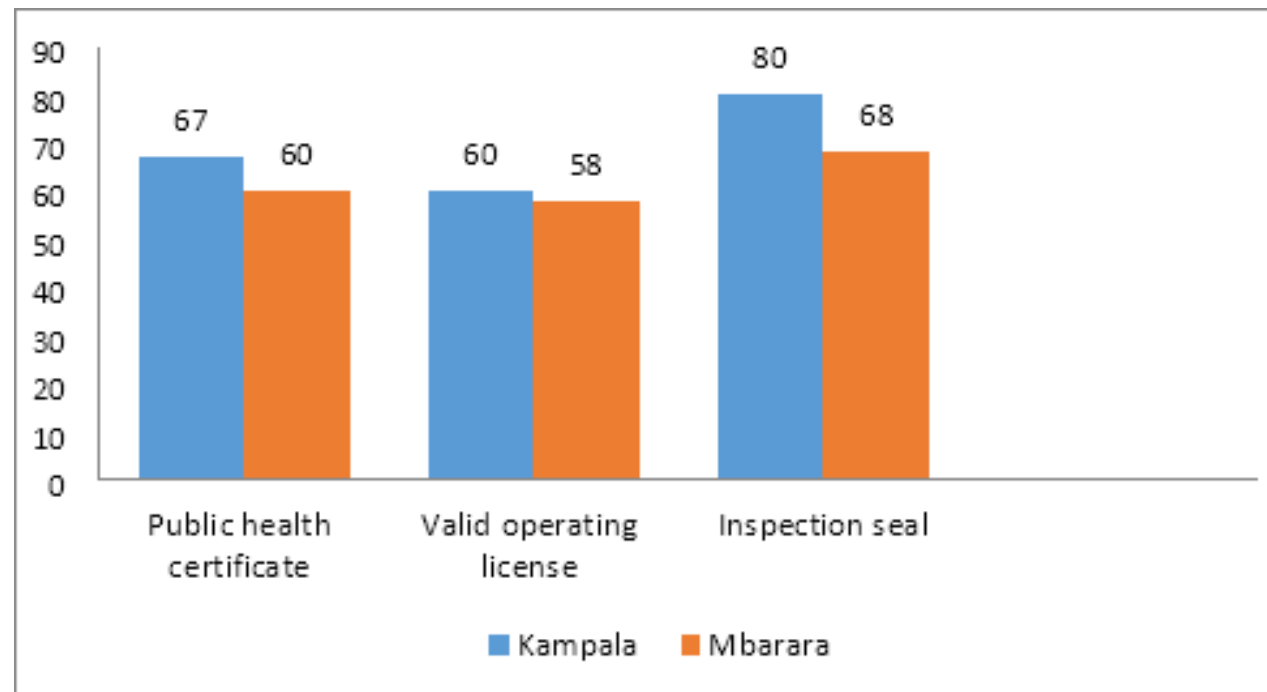

Figure 2

Frequency of use of instruments of certification and inspection

\section{Supplementary Files}

This is a list of supplementary files associated with this preprint. Click to download.

- floatimage2.png 